\title{
Games, Pedagogy and Art Education
}

\section{Jogo, Pedagogia e Arte Educação}

\section{Christine Ballengee Morris}

\begin{abstract}
In 1848, under the auspices of the Smithsonian Institution, Squier and Davis documented what is now referred to as the Newark Earthworks, Ohio USA (SQUIER, DAVIS, 1998 [1848]). Built over two thousand years ago by indigenous peoples, understanding the earthworks has been ongoing. The Octagon Earthwork in Newark, Ohio was named one of the seventy wonders of the ancient world (SCARRE, 1999), and yet this American Indian spiritual space is occupied by a private country club whose golf course winds around the mound. This article provides an introduction to earthworks, the approach to designing interactive curricula, including games and a pedagogy of educational games, which can virtually bring an important site such as the Octagon Earthwork into the classroom.
\end{abstract}

Key-words: Earthworks. Educational games. Native Americans.

Resumo: Em 1848, sob os auspícios da Smithsonian Institution, Squier e Davis documentaram o que hoje é chamado de Newark Earthworks, Ohio, EUA (SQUIER; DAVIS, 1998 [1848]). Construído há mais de dois mil anos pelos povos indígenas, a compreensão dessas obras está sendo desenvolvida. A Earthwork Octágono em Newark, Ohio foi considerado como uma das setenta maravilhas do mundo antigo (SCARRE, 1999), e ainda assim este espaço espiritual dos índios americanos é ocupado por um clube de campo privado cujo campo de golfe corre ao redor do trabalho na terra. Este artigo fornece uma introdução ao Earthwork, a abordagem para a concepção de currículos interativos, incluindo jogos e uma pedagogia de jogos educativos, que podem virtualmente trazer um sitio tão importante quanto o Octógano para a sala de aula.

Palavras-chave: Earthworks. Jogos educacionais. Nativos americanos.

\section{Introduction}

B uilding Earthworks were a central feature of the public architecture of many indigenous cultures in the world. The civilizations that built earthworks around the world often lived in large urban settings. They captured the cadence and mythic qualities of the day and night sky and brought it to earth in the form of monumental, geometric architecture. The Mayans, Egyptians, Middle Archaic Indigenous, the Irish, and the Vikings among others, documented astronomical observances using iconography, arts, and earthworks to communicate their understanding of the world and cosmos.

MORRIS, Christine Ballengee. Games, Pedagogy and Art Education. Informática na Educação: teoria e prática, Porto Alegre, v. 19 n. 1, p. 61-68, jan./maio 2016. 
In the book The Native American, the authors, David Hurst Thomas, Jay Miller, Richard White, Peter Nabokow, and Philip Deloria (1993), explain that the archaeological history of the native peoples of the Americas goes back more than 30,000 years, and that by the time Columbus landed in the New World, it was an old world that had already seen civilizations rise and fall. They claim that the continents were populated by some 75,000,000 people who spoke 2,000 distinct languages and had developed a rich diversity of separate cultures, all linked by a network of trade.

This particular story begins over 2,000 years ago when the Original People of North America built outdoor structures in a place that is now known as Ohio. The locations of the earthworks were always near a water supply, which makes sense for many reasons since the waterways were the ancient highways.

The Newark earthworks were social gathering places, religious shrines, pilgrimage centers, and even astronomical observatories. The builders paid close attention to soil texture and color and knew what type of clay and soil to use so the earthworks would not collapse. In a 1992, an archeological dig at the Great Circle in Newark found that the outside was made with dark earth while the inside was lined with brighter yellow-brown clay. Brad Lepper (1996, p. 22) states: "In Native American societies, different colors have different associations and mean different directions, different soil colors probably had symbolic meaning".

These earthworks were built in various shapes, from simple circles and images of animals to complex structures such as the Octagon Earthworks, which consists of a fifty-acre octagon connected to a twenty-acre circle by two parallel walls. A rounded rectangular Observatory Mound stands along the outer rim of the circle at a point opposite of the octagonal enclosure.

In the early 1980s, Ray Hively, a physicist, and Robert Horn, a philosopher, analyzed the aesthetically ideal geometry of the Octagon (actually a conjoined octagon and circle--see above) for astronomical alignments. Solar alignments were not to be found in the structure, but they found - much to their surprise - several lunar ones. Hively and Horn (1982) determined that the major rising and setting points of the moon, encompassing an 18.6 year cycle, are incorporated into the architecture of the Newark Earthworks. They speculate that this astronomical information is not just symbolically encoded into the site plan, but that the substantial earthen walls, with their long sight lines and a height that corresponds, more or less, to eye level, are massive (and therefore long-lived and tamper proof) fixed instruments for making astronomical observations. Geographically, the Octagon is positioned in an area that needed little clearing for a sightline.

There are also relationships between Newark Earthworks and other earthworks in Ohio, which has been made evident in the ratio of arc distance to longitude difference, infer precise understanding of the mathematical ratio of latitude to longitude and a precise understanding of astronomic constants and the scale of the earth. The redundancy of expression of the same relationships makes it very difficult to discount the relationships as coincidental. I conclude that the builders of the Middle Ohio Earthworks understood aspects of astronomy, scale and shape of the earth, their location on the earth, and how to place find and point position. 


\section{The Visuals}

Native arts, including the Earthworks, are closely related to cultural identities and connect space and spirituality, which gives conceptual basis for understanding place and space within traditional native cultures. As Vine Deloria (1969) states spirituality is a way of Native life, which differs from non-Natives who compartmentalize. What this means, to me, is that words, spaces, music, dance or visual arts, are the celebration of human continuity with the earth and identity. Specific ties to the land unite communities and reflect worldviews. As Steven Leuthold (1998) states in his book Indigenous Aesthetics, cardinal directions in many native worldviews locates humans in relation to the cosmos in a profound, mythic way. Mythic space is commonly arranged around a coordinate system of cardinal points and a central vertical axis. This construct may be called cosmic, for its frame is defined by events in the cosmos, which speaks to landscape design and theory taught at many universities today.

Elders from many tribes recall that the people were farmers, fishers, hunters, and gatherers of wild plant foods. They lived in small villages scattered along the major tributaries of the Ohio River - especially the Great and Little Miami, the Scioto, and Muskingum rivers. From many archaeological digs, Blosser (personal communication) ${ }^{1}$ from the Ohio Historical Society (quasi government agency that is in charge of this site) states that the earthwork builders were also known for their magnificent works of art they crafted from materials gleaned from the ends of their world: copper from the upper Great Lakes, mica from the Carolinas, shells from the Gulf of Mexico, and obsidian, a black volcanic glass, from the Rocky Mountains. These exotic materials may have come to Ohio as valued commodities in a network of trade, but there is little evidence of what items the traders might have given in exchange. Knives and bladelets made from Ohio's beautiful Flint Ridge flint are found scattered throughout eastern North America, but not in the quantities that would suggest a fair trade for the bushels of mica and copper found at Ohio Hopewell sites.

During a tour at Fort Ancient Earthworks in Ohio, the director, Jack Blosser (2014) spoke about the significance of the arts. At their museum at the site, there are ceramics, musical instruments (flutes), jewelry, and fabric pieces, as well as archeological evidence of ceremonial spaces. These societies had the time to create and celebrate.

\section{Game-based Learning}

When playing games, creative thinking, image making, gathering multiple perspectives, making connections, and reflective thinking occurs (AUBRECHT; BALLENGEE-MORRIS, 2013). Additionally, many art educators have been using Second Life, an online virtual environment, to explore identity issues. Second Life "[...] encourages the kinds of learning we believe are most meaningful in art education - interactive, collaborative, inquiry-based, constructive, connected, interdisciplinary, and relevantly provocative [...]" (TAYLOR; BALLENGEE-MORRIS; CARPENTER, 2010, p. 215).

\footnotetext{
${ }^{1}$ J. Blosser, presentation on June 19, 2014, Fort Ancient, Ohio.
} 
Technology, in general, can allow a teacher to move into the role of facilitator to partner (PRENSKY, 2010) and coach and advisor (SQUIRE, 2011). Teachers can guide students in thoughtful and researched sharing of ideas, recognizing that they themselves do not have to know all of the answers. The role of the student can also be transformed from passive receiver of knowledge to active producer (JENKINS, 2006; GEE; HAYES, 2011; PRENSKY, 2010; SQUIRE, 2011). Video games provide powerful and complex learning tools and environments through their inherent ability to combine such multimedia as video, sound, text (including narrative), visual information (images, tables, graphs), and simulations, including pulling information from databases in real time.

Digital games in the classroom and how games are utilized has been an interest to the project that we call Earthworks Rising. In the past, the earthwork builder culture has been poorly addressed in student learning materials. Through game play, we hope players gain a deeper understanding of the culture and grasp, to some degree, the profound and complex issues faced by those who study a culture that has left no written records. The idea for the development of the games is in keeping with James Gee's idea of Big G and Little G - The game is the software in the box and all the elements of in-game design. The Game is the social setting into which the game is placed, all the interactions that go on around the game. Building upon this idea, we built out from the game, through a website and developed a free, self-sustaining learning community (i.e. http://apolyton.net/). The website host mini games, documentaries, explorations, challenges, and links to other sites of partner organizations. Through the multiple digital systems, the study of visual culture including the games, artifacts, earthworks, and contemporary art forms are explored².

Use of video games in the classroom incorporates and connects to many $21^{\text {st }}$ century skills, helping students understand visual culture using something they are already familiar with - video games. Integrating games into the classroom curriculum applies current research to teaching and leaning.

Huang and Tettegah (2010, p. 138) explains that serious games provide "[...] information about current issues and topics such as health, environment, and human rights [...]" and "[...] have also become a major medium to train and teach skills such as social etiquette and pro-social behavior [...]" (HUANG; TETTEGAH, 2010, p. 138). They suggest that game designers consider a player's cognitive load in relationship to their ability to experience empathy during game play; if the player lacks prior understanding of a particular situation, and must therefore develop empathy while simultaneously acquiring an understanding of the situation, they will likely experience cognitive overload "[...] due to the dual-tasking if the game environment, characters, and activities lacks empirical ground [...]" (HUANG; TETTEGAH, 2010, p. 145). They explain that while some research has explored the relationship between learning, emotions, and empathy, "[...] cognitive load and empathy in serious games has not been systematically investigated [...]" (HUANG; TETTEGAH, 2010, p. 145).

Gerdes et al. (2011) outline a social work framework that identifies education components that comprise the options for increasing empathy: affective, cognitive, and decision-making. The game play should involve aspects of affective response (mirroring, mimicry, conditioning) to promote formation of healthy neurological pathways, and cognitive processing (some of which would likely

\footnotetext{
2 This project is funded by the National Endowment for the Humanities (NEH) and the Humanities, Arts, Science, and Technology Alliance and Collaboratory (HASTAC).
} 
include self/other awareness, role-taking, judgment, and perspective-taking) developed through role-playing. Cognitive decision-making may result from game play as the player may be moved to empathetic action demonstrated by helping or advocacy or some other social action.

Contextualizing information and creating immersive environments in which the player takes on a role contributes to a deeper involvement with the topic and leads people to go deeper on their own (GEE, 2007). In making the video games, the questions are: can a video game create a feeling of empathy in the player that extends to real people and other cultures and how do we quantify that given that empathy is a complex emotion?

\section{Background and Contention}

The subject of Native Americans and their role, influence, and cultures in United States schools has traditionally been written about from a colonial perspective, ignoring the native perspective. Several persistent stereotypes have been perpetuated through visual images, movies, and textbooks, stereotypes including noble savage, Indian princess, wise medicine man, etc. (KILPATRICK, 1999). Joe Mcneilly (2008) identified seven common stereotypes of Native Americans found in video games: token Indian, the hunter, the sex object, the warrior, the half-breed, the scout, and the shaman. Additionally, movies and video games often conflate Indian Nations (LAMEMAN apud SHARP, 2011).

Michelle Aubrecht (project coordinator) and myself applied a consulting collaborative approach by interviewing and researching multiple viewpoints/people and carried that method throughout the game design. Smith (2005) states that this process encourages reflective thinking and practice. Consulting collaborative approaches include critical forms of reflective experiences, cultural studies, and research experiences that can challenge established ways of thinking and acting by encouraging a re-examination of one's own values and practices. This process can build learning communities, which will support communities' lifelong successes and achievements through practices that question social problems, policies, and ethical dilemmas. Many art educators have advocated community-based, service-learning approaches for years and quite successfully (CONGDON; BLANDY; BOLIN, 2000; DANIEL, 2001; TAYLOR; BALLENGEE-MORRIS, 2004). Collaborating and working within a coalition is quite a delicate balance.

This game and mini games are still in development or prototyped, and the discussion above relates how we have approached our project. We have tested the website/games in three contexts: elementary art classes, high school, and museum informal setting. Through this process we considered several ways to communicate the educational information while capitalizing on how games can best be used educationally. What games do best is allow for a player to explore an environment, becoming immersed in that environment which in turn provides context for the player to relate their learning and experiences. The context leads the player to seek information that is needed in that moment (GEE, 2008). A game is not the best place to learn facts or demonstrate learning by responding to multiple-choice questions. Rather, games allow for critical and analytical thinking, problem solving, systems thinking, and evidence based reasoning. Games are ideal for helping people to see 
things differently because they create an experience for players that gives them choices that require them to think about what they do. Games also allow players to fail and try again, seeking ways to improve. These are ways of engaging with ideas in larger, big-picture ways, which will, ideally, spur the player to do research and respond outside of the game environment. Our website includes ways for students to go deeper through reading, research, and creating their own response that demonstrates their learning in a creative way such as creating artwork, formal writing or a journal, video, or podcasting.

In this game environment, the focus is on the sky and the cycle of the moon. The user interface gives the player information about the moon for day, month, and year. The Newark Earthworks is structured to observe the Northern most lunar standstill that occurs every 18.6 years. Observing this is the win state and the player must stand on the observatory mound, facing the right direction on the right year of the cycle. Hence, players must manipulate time, position, and orientation in order to advance. To reach this goal, the player will unlock a series of moon positions by collecting markers that correspond to the monthly and yearly cyclical movements of the moon traversing minor to major standstills.

Figure 1 : An image of one of the mini games, Catch the Moon.

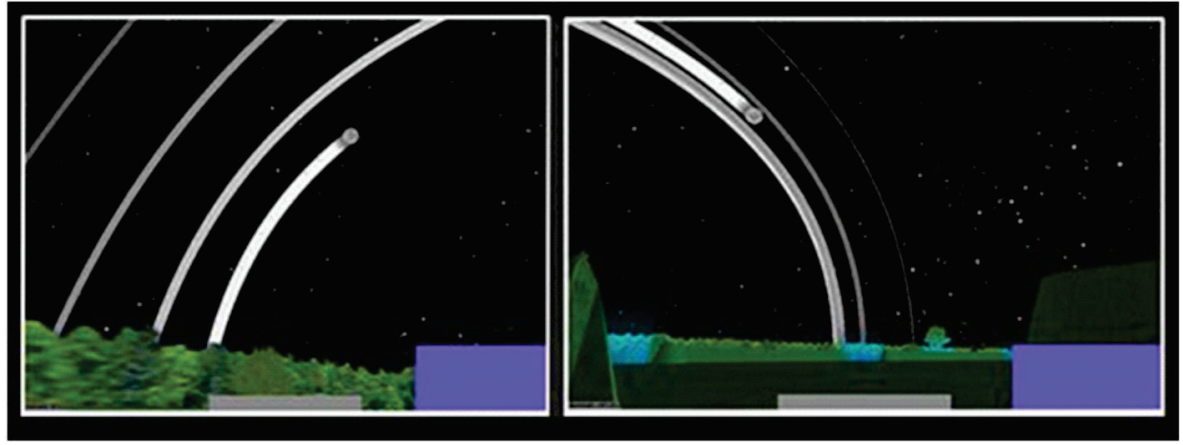

Source: author

\section{Conclusion}

Use of video games in the classroom incorporates and connects to many $21^{\text {st }}$ century skills, helping students understand visual culture using something they are already familiar with - video games. Integrating games into the classroom curriculum applies current research to teaching and leaning. For our students to learn multiple ways of knowing and doing, we must introduce them to sites like the Octagon Earthwork. These sites represent integrated ideologies and imagination. We might never know the extent of how these earthworks were built and utilized but we can imagine. 


\section{References}

AUBRECHT, M.; BALLENGEE-MORRIS, C. Game changing: Developing meet the earthworks builders. In: BAEK, Y. (Ed.). Psychology of Gaming. New York: Nova Publishers, 2013. P.135-150.

CONGDON, K.; BLANDY, D.; BOLIN, P. Histories of community-based art education. Reston, VA: National Art Education Association, 2000.

DANIEL, V. Art education as a community act: Teaching and learning through the community. In: NEW PROSPECTS OF ART EDUCATION IN THEORY AND PRACTICE SYMPOSIUM, 2001, Taipei, Taiwan. Proceedings. Taipei: National Taiwan Normal University, 2001.

DELORIA, V. Custer died for your sins: an Indian manifesto. New York: Macmillan, 1969.

GEE, J.P. Learning and games. In: SALEN, K. (Ed.). The ecology of games: Connecting youth, games, and learning. Cambridge, MA: The MIT Press, 2008. P. 21-24.

GEE, J.P. What video games have to teach us about learning and literacy. 1st ed. New York: Palgrave Macmillan, 2007.

GEE, J.P.; HAYES, E. Language and learning in the digital age. New York: Routledge, 2011.

GERDES, K.E. et al. Teaching empathy: a framework rooted in social cognitive neuroscience and social justice. Journal of Social Work Education, v. 47, n. 1, p. 109-131, 2011.

HIVELY, R.; HORN, R. Geometry and astronomy in prehistoric Ohio. Journal for the History of Astronomy, v. 13, n. 4, S1-S20, 1982. Archaeoastronomy Suppl.

HUANG, R.; TETTEGAH, S. A conceptual framework to understand the relationship between Cognitive load and empathy development in serious games. In: ECK'S, R.V. (Ed.). In Gaming and cognition: Theories and perspectives from the learning sciences. Hershey, PA: IGI Global, 2010. P. 137-150.

JENKINS, H. Convergence culture: Where old and new media collide. New York: New York University Press, 2006.

KILPATRICK, J. Celluloid Indians. Lincoln, NE: University of Nebraska, 1999.

LEPPER, B.T. The Newark Earthworks and the Geometrical Enclosures of the Scioto Valley: Connections and Conjectures. In: PACHECO, P. (Ed.). A View from the Core: A Synthesis of Ohio Hopewell Archaeology. Columbus, OH: Ohio Archaeological Council, 1996. P. 225-241. 
LEUTHOLD, S. Indigenous aesthetics: Native art and identity. Austin, TX: University of Texas Press, 1998.

MCNEILlY, J. (2008, November 24). The top 7... Native American stereotypes. In: GAMESRADAR+. The Ambury, Bath: Future Publ., 2008. Available in: <http://www.gamesradar.com/the-top-7-native-american-stereotypes/>. Acessed: 20 nov. 2011.

PRENSKY, M. Teaching digital natives: Partnering for real learning. London: Corwin, 2010.

SCARRE, C. The Seventy Wonders of the Ancient World. London: Thames \& Hudson, 1999.

SHARP, G. Stereotypes of Native Americans in video games. In: SOCIOLOGICAL Images. [S.I.]: W.W. Norton, 2011. Available in: <http://thesocietypages.org/socimages/2011/08/09/stereotypes-of-native-americans-in-videogames/> Acessed: 20 nov. 2011.

SMITH, T.L. Decolonizing methodologies: Research and Indigenous peoples. London: Zed Books, 2005.

SQUIER, E.; DAVIS, E. H. Ancient Monuments of the Mississippi Valley. Washington : Smithsonian Institution Press, 1998 [1848]. $316 \mathrm{p}$.

SQUIRE, K. Video games and learning: Teaching and participatory culture in the digital age. NYC: Teachers College Press, 2011.

TAYLOR, P.G.; BALLENGEE-MORRIS, C. Service-Learning A language of "we". Art Education, v. 57, n. 5, p. 6-12, 2004.

TAYLOR, P.G.; BALLENGEE-MORRIS, C.; CARPENTER, B.S. Digital visual culture, social networking, and virtual worlds: Second Life and art education. In: SWEENY, R. (Ed.). Digital Visual Culture: Interactions and Intersections in $21^{\text {st }}$ Century Art Education. Reston, VA: National Art Education Association, 2010. P. 210-218.

THOMAS, D.H.; MILLER, J.; WHITE, R.; NABOKOW, P.; DELORIA, P. The Native American. Atlanta, GA: Turner Publishing, 1993.

Submetido para avaliação em 14 de agosto de 2015.

Aprovado para publicação em 01 de março de 2016.

Christine Ballengee Morris - Universidade Estadual de Ohio, Columbus, Ohio - Estados Unidos. E-mail: morris.390@osu.edu 